\title{
Interventricular septal hematoma associated with congenital heart surgery: A case report and literature review
}

Fumiya Yoneyama, MD, Muneaki Matsubara, MD, PhD, Hiroaki Sakamoto, MD, PhD, and

Yuji Hiramatsu, MD, PhD, Tsukuba, Japan

From the Department of Cardiovascular Surgery, University of Tsukuba, Tsukuba, Japan.

Disclosures: Authors have nothing to disclose with regard to commercial support.

Received for publication Sept 19, 2016; revisions received Oct 19, 2016; accepted for publication Oct 28, 2016; available ahead of print Dec 2, 2016.

Address for reprints: Fumiya Yoneyama, MD, Department of Cardiovascular Surgery, University of Tsukuba, 1-11 Tennodai, Tsukuba 305-8575, Japan (E-mail: fumiya.y@ hotmail.co.jp).

J Thorac Cardiovasc Surg 2017;153:e55-7

$0022-5223 / \$ 36.00$

Copyright $(C) 2016$ by The American Association for Thoracic Surgery

http://dx.doi.org/10.1016/j.jtcvs.2016.10.053

Interventricular septal hematoma (IVSH) is extremely rare, and most cases are reported to occur in pediatric patients as a complication after the repair of a ventricular septal defect (VSD). We present a case of a giant IVSH after patch closure of a perimembranous VSD and review of the relevant literature.

\section{CLINICAL SUMMARY}

A 3-month-old boy was admitted to the University of Tsukuba hospital with a diagnosis of VSD and severe pulmonary hypertension. The patient weighed $5.3 \mathrm{~kg}$. Echocardiography revealed a large $(6 \mathrm{~mm})$ perimembranous trabecular VSD, which was surgically closed using cardiopulmonary bypass (CPB) and antegrade cardioplegia. A standard closure using a Dacron patch and a

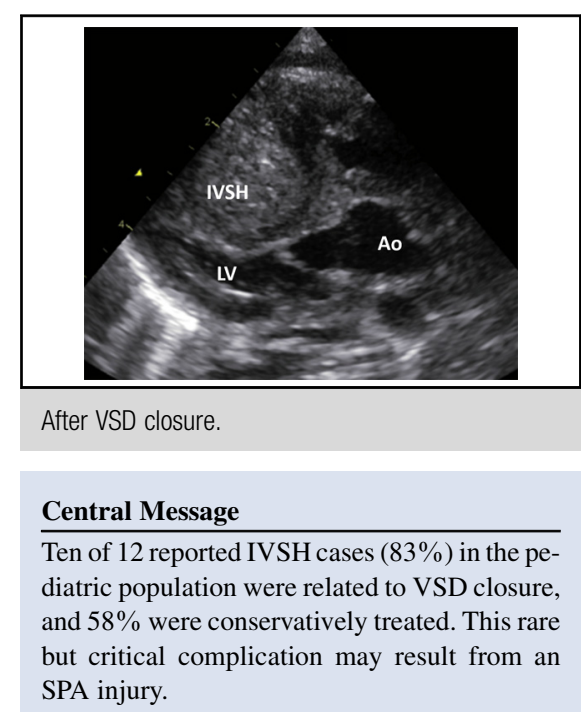

See Editorial Commentary page e59.

continuous suture technique along the edge starting with a pledgeted horizontal mattress suture placed near the base of the medial papillary muscle was performed.
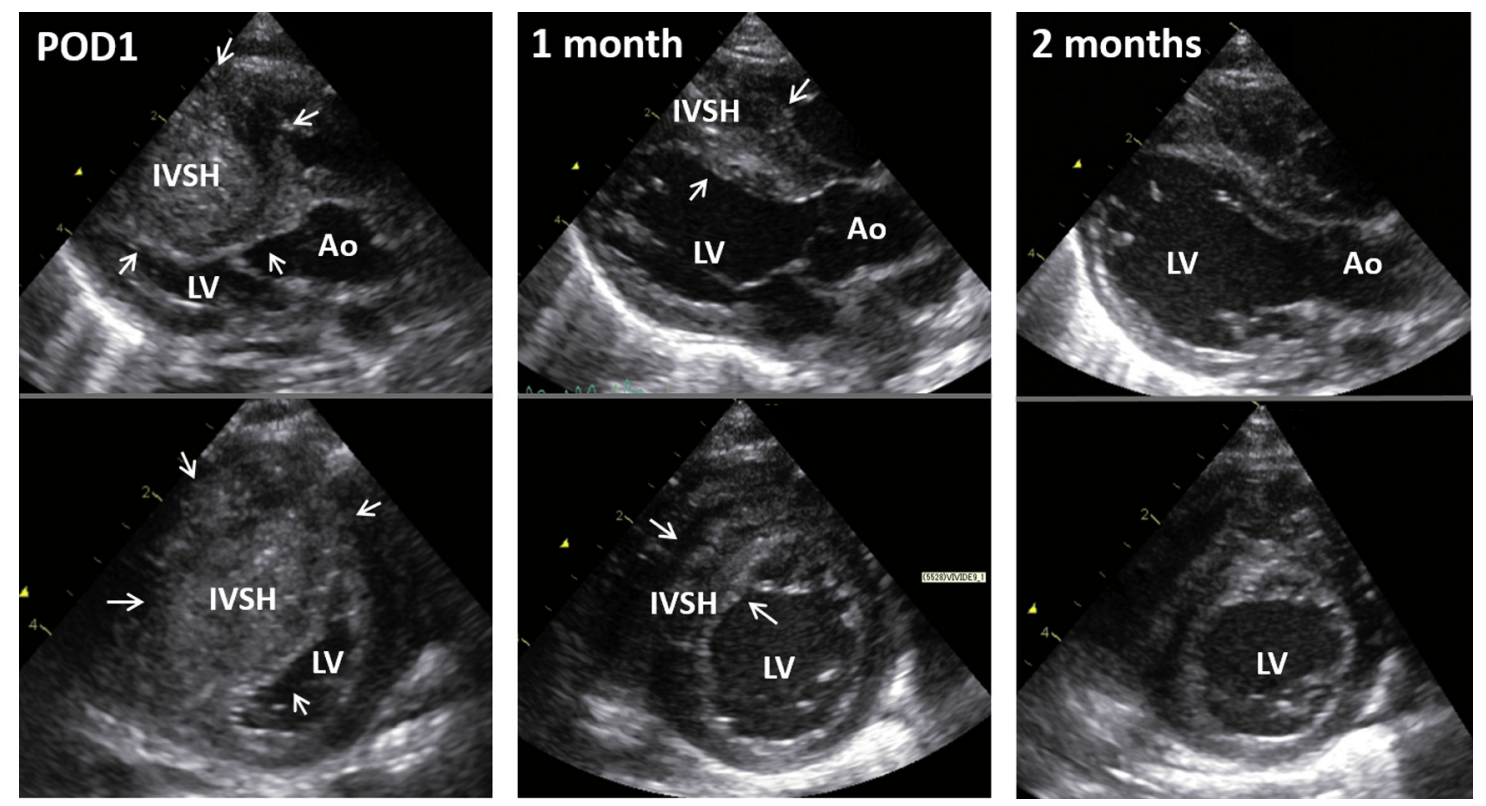

FIGURE 1. TEE showing changes in the interventricular septum hematoma over time. Longitudinal (top) and short-axis (bottom) views on postoperative day 1, month 1, and month 2. Arrows indicate hematoma. POD, Postoperative day; IVSH, interventricular septal hematoma; $L V$, left ventricle; Ao, aorta. 
TABLE 1. Reported cases of interventricular septum hematoma associated with congenital heart defect corrective surgery

\begin{tabular}{|c|c|c|c|c|c|c|c|c|c|c|}
\hline Reference & $\begin{array}{c}\text { Year } \\
\text { published }\end{array}$ & $\begin{array}{c}\text { No. of } \\
\text { patients }\end{array}$ & $\begin{array}{l}\text { Age and } \\
\text { gender }\end{array}$ & Diagnosis & $\begin{array}{c}\text { Surgical } \\
\text { procedure }\end{array}$ & $\begin{array}{c}\text { Hemodynamic } \\
\text { instability }\end{array}$ & $\begin{array}{c}\text { Abnormal } \\
\text { ECG findings }\end{array}$ & $\begin{array}{c}\text { Surgical } \\
\text { intervention } \\
\text { for IVSH }\end{array}$ & $\begin{array}{l}\text { Time for } \\
\text { IVSH } \\
\text { resolution }\end{array}$ & Outcomes \\
\hline $\begin{array}{l}\text { Drago and } \\
\text { colleagues }^{1}\end{array}$ & 2005 & 1 & $4 \mathrm{mo}, \mathrm{N} / \mathrm{A}$ & $\begin{array}{l}\text { Perimembranous } \\
\text { VSD }\end{array}$ & $\begin{array}{l}\text { VSD patch } \\
\text { closure }\end{array}$ & + & $\begin{array}{c}+ \\
\text { ST elevation }\end{array}$ & $\begin{array}{c}\text { Incisional } \\
\text { drainage } \\
\text { on CPB }\end{array}$ & $20 \mathrm{~d}$ & Discharged \\
\hline $\begin{array}{l}\text { Padalino and } \\
\text { colleagues }^{2}\end{array}$ & 2006 & 1 & $4 \mathrm{mo}$, female & $\begin{array}{l}\text { Perimembranous } \\
\text { VSD }\end{array}$ & $\begin{array}{l}\text { VSD patch } \\
\text { closure }\end{array}$ & - & $\begin{array}{r}+ \\
\text { Wide QRS } \\
\text { complex }\end{array}$ & $\begin{array}{c}\text { Drainage } \\
\text { with a } \\
16-\mathrm{G} \\
\text { needle }\end{array}$ & $8 \mathrm{~d}$ & Discharged \\
\hline \multirow[t]{2}{*}{$\begin{array}{l}\text { Jensen and } \\
\text { colleagues }^{3}\end{array}$} & 2007 & 2 & $2 \mathrm{~d}, \mathrm{~N} / \mathrm{A}$ & $\begin{array}{l}\text { Malalignment } \\
\text { VSD, interrupted } \\
\text { aortic arch }\end{array}$ & $\begin{array}{l}\text { VSD patch } \\
\text { closure } \\
\text { Arch } \\
\text { reconstruction }\end{array}$ & - & - & - & $\begin{array}{l}\text { A few } \\
\text { months }\end{array}$ & Discharged \\
\hline & & & $3 \mathrm{mo}, \mathrm{N} / \mathrm{A}$ & $\begin{array}{l}\text { Perimembranous } \\
\text { VSD }\end{array}$ & $\begin{array}{l}\text { VSD patch } \\
\text { closure }\end{array}$ & + & $\begin{array}{c}+ \\
\text { AVB and JET }\end{array}$ & - & $2 \mathrm{mo}$ & Discharged \\
\hline $\begin{array}{l}\text { Zuhang and } \\
\text { colleagues }^{4}\end{array}$ & 2008 & 1 & $7 \mathrm{y}$, male & $\begin{array}{l}\text { Perimembranous } \\
\text { VSD }\end{array}$ & $\begin{array}{l}\text { VSD patch } \\
\text { closure }\end{array}$ & + & $\begin{array}{c}+ \\
\mathrm{VT}\end{array}$ & $\begin{array}{c}\text { Incisional } \\
\text { drainage } \\
\text { on } \mathrm{CPB}\end{array}$ & N/A & $\begin{array}{l}\text { Died suddenly } \\
\text { at } 8 \mathrm{mo}\end{array}$ \\
\hline $\begin{array}{l}\text { Mart and } \\
\text { colleagues }\end{array}$ & 2011 & 1 & $3 \mathrm{mo}$, male & $\begin{array}{l}\text { Perimembranous } \\
\text { VSD }\end{array}$ & $\begin{array}{l}\text { VSD patch } \\
\text { closure }\end{array}$ & + & $\begin{array}{r}\text { Data not } \\
\text { shown }\end{array}$ & $\begin{array}{c}\text { Incisional } \\
\text { drainage } \\
\text { on CPB }\end{array}$ & $\begin{array}{l}\text { Data not } \\
\text { shown }\end{array}$ & Discharged \\
\hline \multirow[t]{3}{*}{$\begin{array}{l}\text { Zhu and } \\
\text { colleagues }^{6}\end{array}$} & 2012 & 2 & $3 \mathrm{mo}$, male & $\begin{array}{l}\text { Perimembranous } \\
\text { VSD }\end{array}$ & $\begin{array}{l}\text { VSD patch } \\
\text { closure }\end{array}$ & + & $\begin{array}{c}+ \\
\text { JET }\end{array}$ & Considered & N/A & $\begin{array}{l}\text { Died before } \\
\text { intervention }\end{array}$ \\
\hline & & & $7 \mathrm{mo}$, female & $\begin{array}{l}\text { Tetralogy of } \\
\text { Fallot }\end{array}$ & $\begin{array}{l}\text { VSD patch } \\
\text { closure }\end{array}$ & + & + & - & $3 \mathrm{mo}$ & Discharged \\
\hline & & & & & $\begin{array}{l}\text { RVOT } \\
\quad \text { reconstruction }\end{array}$ & & JET & & & \\
\hline $\begin{array}{l}\text { Eyileten and } \\
\text { colleagues }^{7}\end{array}$ & 2013 & 1 & $10 \mathrm{mo}, \mathrm{N} / \mathrm{A}$ & $\begin{array}{l}\text { Perimembranous } \\
\text { VSD }\end{array}$ & $\begin{array}{l}\text { VSD patch } \\
\text { closure }\end{array}$ & - & $\begin{array}{c}+ \\
\text { ST depression }\end{array}$ & - & $6 \mathrm{mo}$ & Discharged \\
\hline $\begin{array}{l}\text { Suteu and } \\
\text { colleagues }^{8}\end{array}$ & 2016 & 1 & $21 \mathrm{~d}, \mathrm{~N} / \mathrm{A}$ & $\begin{array}{l}\text { Pulmonary } \\
\text { valve stenosis }\end{array}$ & $\begin{array}{l}\text { RVOT } \\
\quad \text { reconstruction }\end{array}$ & - & Data not shown & - & $6 \mathrm{mo}$ & Discharged \\
\hline $\begin{array}{c}\text { Bernasconi and } \\
\text { colleagues }^{9}\end{array}$ & 2016 & 1 & $14 \mathrm{~d}$, male & TAPVR & $\begin{array}{l}\text { TAPVR } \\
\text { correction }\end{array}$ & + & Data not shown & - & $11 \mathrm{~d}$ & Discharged \\
\hline Present case & & 1 & $3 \mathrm{mo}$, male & $\begin{array}{l}\text { Perimembranous } \\
\text { VSD }\end{array}$ & VSD patch closure & - & - & - & $2 \mathrm{mo}$ & Discharged \\
\hline
\end{tabular}

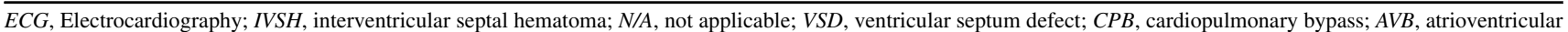
block; $J E T$, junctional ectopic tachycardia; $V T$, ventricular tachycardia; $R V O T$, right sventricular outflow tract; $T A P V R$, total anomalous of pulmonary venous return.

Upon weaning from CPB, transesophageal echocardiography (TEE) revealed an abnormal 18.1-mm thickening of the interventricular septum with an internal, mixed sonic mass, which was consistent with the findings of a giant IVSH. Ventricular septal motion was hypokinetic, and close TEE monitoring was maintained for approximately $30 \mathrm{mi}-$ nutes with the patient still on CPB. The IVSH did not enlarge, and no critical events such as lethal arrhythmia, septal perforation, or ventricular asynergy occurred. The hemodynamics were unexpectedly stable, except for sinus tachycardia. Both ventricular outflow tracts seemed slightly obstructed, but TEE detected no significant pressure gradients. The patient was taken off CPB and conservatively managed without an immediate surgical drainage.

The patient had several asthma attacks and airway obstruction episodes, and therefore needed careful respiratory management on mechanical ventilation until postoperative day 23. Serial transthoracic echocardiograms confirmed a significant reduction in the size of the IVSH by this time. The patient was discharged 2 months after surgery when transthoracic echocardiograms showed complete resolution of the hematoma and normal thickness and normal motion of the interventricular septum (Figure 1).

\section{DISCUSSION}

IVSH occurs in adults after chest trauma, myocardial infarction, or various cardiac procedures. It is an extremely rare complication of congenital heart surgery; only 11 cases have been described since $2005 .{ }^{1-9}$ Table 1 shows the demographics and clinical outcomes of 12 pediatric IVSH cases, including the present case. Patient age ranged from 2 days to 7 years, with 10 occurrences $(83 \%)^{1-7}$ requiring VSD closure, most of them being the perimembranous type. This suggests that surgical manipulation of the perimembranous ventricular septum contributes to the development of IVSH.

Seven patients ${ }^{1,3-6,9}$ were hemodynamically unstable after the development of IVSH, 3 of whom ${ }^{3,6,9}$ were conservatively treated without surgical intervention. Two 
patients underwent incisional drainage of IVSH on CPB with good outcomes. ${ }^{1,5}$ One patient suddenly died of an unknown cause 8 months after incisional drainage ${ }^{4}$; the second patient collapsed and died immediately after the VSD patch closure without time for surgical intervention. ${ }^{3}$

Five patients, including ours, were hemodynamically stable; 4 patients were discharged without drainage. $2,3,7,8$ Seven patients $(58 \%)$ were conservatively managed, and all of them survived. Although we recognize the importance of prompt management of IVSH, aggressive surgical intervention is evitable, especially when patients are hemodynamically stable. The time required for IVSH resolution varied with each case and widely ranged from 11 days to 6 months with conservative management.

The cause of IVSH is unclear, but it may be related to injury of the septal perforating artery (SPA). ${ }^{10}$ Anatomically, the first SPA crosses the lower border of the anterior limb of the septomarginal trabeculation and terminates at the base of the medial papillary muscle of the tricuspid valve. ${ }^{11}$ Although the branches of the first SPA vary considerably in pattern and depth, Hosseinpour and colleagues ${ }^{12}$ described that the areas surrounded by the outlet septum, the medial papillary muscle, and the margin of the VSD are generally devoid of the first SPA. The VSD patch sutures should be carefully placed on this "devoid area" to avoid possible SPA injury. Because the SPA supplies a critical portion of the interventricular conduction system, including the 2 main bundle branches and Purkinje arborization, ${ }^{13}$ IVSH may lead to not only ventricular dysfunction but also various types of lethal arrhythmias. ${ }^{4}$

\section{CONCLUSIONS}

Our case and the literature review highlight that IVSH in the pediatric population mostly occurs after VSD closure, with underlying SPA injury as a possible cause. Although a timely management of IVSH is important, urgent surgical drainage is not required when hemodynamics are stable because all reported patients on conservative treatment survived.

\section{References}

1. Drago M, Butera G, Giamberti A, Lucente M, Frigiola A. Interventricular septal hematoma in ventricular septal defect patch closure. Ann Thorac Surg. 2005;79: 1764-5.

2. Padalino MA, Speqqiorin S, Pittarello D, Milanesi O, Stellin G. Unexpected interventricular septal hematoma after ventricular septal defect closure: intraoperative echocardiographic early detection. Eur J Echocardiogr. 2007;8:395-7.

3. Jensen R, Burg P, Anderson C, Garabedian C, Garabedian H, Siwek L, et al. Postoperative ventricular septal hematoma: natural history of two pediatric cases. $J$ Thorac Cardiovasc Surg. 2007;133:1651-2.

4. Zhuang J, Chen JM, Huang X. Interventricular septal dissecting haematoma. Eur Heart J. 2008;29:2488.

5. Mart CR, Kaza AK. Postoperative dissecting ventricular septal hematoma: recognition and treatment. ISRN Pediatr. 2011;2011:534940.

6. Zhu J, Liu H, Zhang J, Feng X, Wu S, Mei J, et al. Interventricular septal hematoma after congenital cardiac surgery. Ann Thorac Surg. 2013;95:2171-3.

7. Eyileten Z, Aliyev A, Ciftci O, Ucar T, Odek C, Kendirli T, et al. An extremely rare complication of congenital heart surgery: inverventricular septal hematoma. Turk J Pediatr. 2013;55:662-4.

8. Suteu CC, Muntean I, Benedek T, Toganel R. Giant dissecting ventricular septal hematoma associated with critical congenital heart disease. Interact Cardiovasc Thorac Surg. 2016;23:837-8.

9. Bernasconi A, Cavalle-Garrido T, Redington A. Spontaneous intraoperative ventricular hematoma in a neonate. Heart. 2007:93:898.

10. Vargas-Barrón J, Roldán FJ, Romero-Cárdenas A, Molina-Carrion M, VazquezAntona CA, Zabalgoitia M, et al. Dissecting intramyocardial hematoma: clinical presentation, pathophysiology, outcomes and delineation by echocardiography. Echocardiography. 2009:26:254-61.

11. Melo JQ, Abecassis M, Neves J, Calquinha J, Ramos S, Martins AP, et al. Can the location of the large septal artery be predicted? Eur J Cardiothorac Surg. 1995;9: 628-30.

12. Hosseinpour AR, Anderson RH, Ho SY. The anatomy of the septal perforating arteries in normal and congenitally malformed hearts. J Thorac Cardiovasc Surg. 2001;121:1046-52.

13. James TN, Burch GE. Blood supply of the human interventricular septum. Circulation. 1958;17:391-6. 